\title{
An Introduction of Purchase Types and Happiness
}

\author{
Zining Peng, Maolin Ye \\ School of Management, Jinan University, Guangzhou, China \\ Email: morning.jnu@gmail.com, maolinye@163.com
}

Received 31 December 2014; accepted 25 February 2015; published 28 February 2015

Copyright (C) 2015 by author and Scientific Research Publishing Inc.

This work is licensed under the Creative Commons Attribution International License (CC BY). http://creativecommons.org/licenses/by/4.0/

c) (7) Open Access

\begin{abstract}
Experiential purchases refer to the purchase aiming to get life experience, while material purchases define the purchase made to acquire material possession. Both purchase types have different effects on happiness for the individual and experiential purchases which can make people feel happier and more joyful than material purchase. The reasons exist in the following five areas: firstly, as improved over time, experience is becoming better and better; secondly, experience has closer links with itself; what's more, experiential purchase, instead of material purchase, will not arouse social comparison; fourthly, experience can meet the basic psychological needs of people, especially the relationship needs; last but not least, experience is easy to share.
\end{abstract}

\section{Keywords}

Experiential Purchase, Material Purchase, Happiness

\section{Introduction}

With the continuous growth of China's economy, people's basic food and clothing problem has been resolved, and discretionary income increases gradually. People not only purchase to meet basic survival needs, but also own the economic ability to purchase more diverse items to satisfy the needs of different aspects. It has become one of the people's concerns that how to spend money to "buy" more joy and happiness. An advertisement from LEXUS company said that "Money can not buy joy, because of using it in the wrong way." Similarly, Diener, Horwitz, and Emmons (1985) also pointed out that "money not only can increase happiness but also can reduce it, which mainly depends on the method of use" [1]. So how to use money to get happy? In life, some people use money to buy material items, such as jewelry, clothes and electronic products, while others are willing to spend money on outdoor activities, tourism and other activities to get a special experience. Research shows that people's consumption patterns and happiness are closely related. 


\section{Conception and Measurement of Experiential Purchase and Material Purchase}

According to customers' purchasing intentions, Van Boven and Gilovich (2003) first proposed two different consumption and purchase type: experiential purchases and material purchases [2]. Experiential purchases means that through a purchase behavior to obtain life experience or get an experience, such as travel, watching performances, concerts, eating out, etc.; material purchases refers to the purchase of physical commodities such as clothes, jewelry, electronic products, furniture, etc. As can be seen from the definition, the biggest difference between the experiential purchases and material purchases is the different purpose for the purchase, the experiential purchases emphasizes on "process and experience", while material purchases focus on "save and possession” (Carter \& Gilovich, 2012) [3]. Secondly, experiential purchases is about to purchase the remaining memories of this experience, you can use language to describe it but intangible; material purchases is occupied by a certain physical space and you can touch and see the tangible goods. Finally, the items get from material purchases can be preserved as a possession; while when purchasing experience, consumers can only go to experience and enjoy for a limited time. From an economic perspective, material purchases corresponds manufacturing economy and experiential purchases corresponds to service economy (Carter \& Gilovich, 2012) [3].

Experiential purchases and material purchases are not dichotomous variables, they can be seen as both ends of this continuum purchase type (Nicolao, Irwin, \& Goodman, 2009), so there is a gray zone between the two types of purchase [4]. While in previous studies, consumers were asked to recall the time of purchasing, consumers rarely feel puzzled of classification criteria of the two types, and the type of assessment results were consistent with the vast majority of consumer classification by a third party, indicating little purchase fuzziness caused by the impact of type (Carter \& Gilovich, 2014), but it can not be denied that there is prone to confusion between the two types of purchase [5]. With deepening of the research, it is urgent need to have a more precise classification criteria to clarify the two types' relationship. Currently, for the purchase and consumption which not clearly distinguished easily lead to ambiguity, the only criteria for the classification of them is the initial intention and purpose of purchase, and the original source of happiness of purchase brought (Van Boven, 2005; Van Boven \& Gilovich, 2003; Carter \& Gilovich, 2014) [2] [5] [6]. Such as buying a guitar, it is experiential purchase if for playing while material purchase for collection (Carter \& Gilovich, 2014) [5]. Carter and Gilovich (2012) used this method cleverly [3]. Controlling the purchase intention, they used a test to started consumers' experiential purchases and material purchases through a 3D TV_as the 3D TV a high-end goods to possess is material purchases while in order to get a better viewing experience is experiential purchases.

Materialistic purchase is a similar kind of material purchases on the English expression, but not the same concept. As mentioned above, the material purchases, which correspond experiential purchases, refers to purchase tangible goods, focusing on the ownership of items. Materialistic purchase derived from materialism and it is one's values that emphasizes the importance of possessing material wealth (Richins \& Dawson, 1992) [7], materialistic purchase wants to highlight his wealth or status (Carter \& Gilovich, 2012) [3]. In view of this, no matter what type of purchase, as long as the purchase is to highlight the wealth or status, it can be considered as materialistic purchase.

With the development of research, the scale related to the purchase's type achieved some progress. Howell, Pchelin and Iyer (2012) developed Experiential Buying Tendency Scale (EBTS), which is used to understand and assess individual's choice made when buying-experiential purchase or materialistic purchase propensity, as a individual habitual purchase, this tendency, is a long-term stability characteristics. Scale for single dimension, constituted by the four topics, such as, "Some people spend most money on different life experiences, such as dining out, concerts, travel, etc. They enjoy life through participation in activities. You think this characteristics match you in which extent?”. Scale of 1 to 7: scoring 1 indicates “totally inconsistent”, 7 means “fully compliant”. Internal consistency coefficients between 0.75 to 0.77 .

\section{Relationship between Experiential Purchase, Material Purchase and Happiness}

Van Boven and Gilovich (2003) first proposed that experiential purchase and material purchase have diverse effects on individual happiness, and people feel even happier by experiential purchase [2]. At present, the distance of this groundbreaking research has been 10 next year, more researches have emerged a common concern is the relationship between the purchase type and purchase-related well-being. And the findings are consistent that compared to material purchase, the experiential purchase give consumers more pleasant experience, greater satisfaction and purchase-related well-being (Caprariello \& Reis, 2013; Carter \& Gilovich, 2010, 2012; Howell \& 
Hill, 2009; Nicolaoetal, 2009;. Rosenzweig \& Gilovich, 2012; Thomas \& Millar, 2013) [3] [4] [8]-[12]. Nicolao et al. (2009), called this phenomenon "experience recommendation". With further research, the researchers noted that "experience recommendation" has a certain scope [4].

First, "experience recommendation" influenced by the effect of outcome of buying. Nicolao et al. (2009) took experiential purchase and material purchase's titer results into account [4]. Subjects were asked to recall a result of the good (or bad) experience of experiential purchase (material purchase) respectively, then measured their happiness. The results show that the "experience recommendation" only applies to the positive result of the purchase, that is, when the result is positive, experiential purchase gives consumers more happiness than material purchase. It also verifies Van Boven and Gilovich's findings (2003) [2]. But when the result is negative, compared to material purchase, experiential experience can not bring more happiness, the "experience recommendation" phenomenon disappeared. In short, the impact of purchasing type on happiness changes with the result of the purchase potency, Van Boven and Gilovich's (2003) findings only apply to the case of a positive result of the purchase, and does not apply to the purchase of a negative outcome [2].

Secondly, "experience recommendation" affected by consumers' personality, mainly affected by the level of materialism. Materialist has the following characteristics: 1 ) tends to make materialistic purchase; 2) by highlighting the wealth to get happy; 3) to measure success based on wealth; 4) defined themselves and others by the level of consumption, status and wealth (Richins \& Dawson, 1992) [7]. Thus, whether materialist value material purchase, material purchase can bring them more happiness? Millar and Thomas' (2009) study shows that materialism regulate the relationship between the type of purchase and happiness: materialistic get more pleasure from material purchase, but for experiential purchase, it does not affect the level of materialism and happiness' relationship, that is, regardless of the level of materialism, experiential purchase always bring more happiness than material purchase [13]. Meanwhile, Nicolao et al. (2009) also pointed out that materialism has a regulatory role in the inter-purchase type and satisfaction: When purchase's result is positive, non-materialist is more satisfied with the experiential purchase, and materialist has no difference in satisfaction of experiential purchase and material purchase [4]. Howell et al. (2012) considered non-materialist prefer buying experience, because it can meet their basic psychological needs so as to enhance the subjective well-being [14]. Different from above results, some studies show that materialism does not play a regulate role in the relationship between purchase type and degree of happiness (Bastos, 2012; Carter \& Gilovich, 2012; Thomas, 2010) [3] [12] [15]. Therefore, whether materialism variables play a role in "experience recommendation" or not are still a non-uniform conclusion, and need to more follow-up studies.

In addition to the results of potency and personality traits, researchers also examined the impact of the purchase price to the relationship of purchase type and happiness. In Some research, the purchase price was limited. subjects were asked to recall their experience of material purchase and experiential purchase, at the price levels of $\$ 50$ or more (Carter \& Gilovich, 2010), $\$ 100$ or more (VanBoven \& Gilovich, 2003) as well as $\$ 300$ (Nicolao et al., 2009). Analysis showed that price has no effect on the relationship between the purchase type and happiness. Some other studies have not limited the scope of the purchase price, only regarded it as a measure, andthe price of purchase was reported, also achieved the same result, the price of the purchase has not effect on the relationship between purchase type and happiness, also on satisfaction with the purchase (Howell \& Hill, 2009; Millar \& Thomas, 2009; Van Boven, Campbell, \& Gilovich, 2010) [10] [13] [16]. Thus, regardless of whether the purchase price controlled or not, the price did not have a significant impact on the relationship between the type of purchase and happiness, but as a typical feature of purchase, price is still one of the considerations in current research.

In addition, socioeconomic status (SES) also plays a part in the relationships between the type of purchase and happiness. SES has an regulate effect on the purchase type and happiness, compared to the experiential purchase, material purchase give more happier to people with low SES; for people with high SES, purchase type has no influence on happiness (Thomas \& Miller, 2013) [12]. From the demographic perspective, during November to December of 2000, the researchers conducted a telephone survey of the United States. 1263 respondents, aged 21 to 69 years, were asked to answer the question: "Choosing one of your past experiential purchase and one of your past material purchase, which one make you feel more happier?” 57\% of respondents believe that the experiential purchase make more happiness, only 34 percent of respondents believe the material purchase make more happiness. Female, the young, high-income earners, higher education level people, people living in cities and suburbs feel more happiness from experiential purchase than male, the elderly, low-income earners, low education level people and people living in rural areas (Van Boven \& Gilovich, 2003) [2]. 


\section{Theory Explanation of the Relationship between Purchase Types and Happiness}

Why people feel happier when doing experiential purchase than material purchase? In the past, researchers explore this theme mainly from individual level and interpersonal level. Firstly, at the individual level, researchers discusses the impacts of two purchase ways on happiness over time from a cognitive perspective; Then, from the perspective of self-interpretation, researchers try to explain the relationship between two purchase ways and itself, and two ways of buying and basic needs satisfactory, especially the relationship between demand. Secondly, at the interpersonal level, from the perspective of the social impact, they try to explain why social comparison and share would result in different happiness levels brought by two different ways to consumers.

\subsection{Experience Improved over Time}

Construal level theory (CLT) pointed out that people's interpretation of events will change with the perception of psychological distance of events such as the time distance, spatial distance. In terms of long psychological distance events, people tend to use high-level construal, that is, characterizing a incident from abstract, core and partical features; as to short psychological distance events, people tend to use low level construal, such as from the concrete, and the surface features to characterize local events (Liberman \& Trope, 1998) [17]. Carter and Gilovich (2010) consider the experiential purchase is stored in an individual's mind as memory, and the purchase goods have always been around [9]. Compared to the article, people often think and recall the experience (Dunn, Gilbert, \& Wilson, 2011) [18]. Van Boven et al. (2003) investigated 40 students from Cornell University, 83 percent of respondents answered that "the number of recalls of experiential purchase is more than that of material purchase” [2]. Thoughts and memories, distinct from direct experience, are all psychological explanation and represent the psychological distance thing (Trope \& Liberman, 2010) [19]. Thus, as the time goes on, compared to the material purchase, consumers can explain experience in a higher and more abstract level (Van Boven, 2005) [6].

In the memory, experiential purchase has more useful processing than material purchase, thus, consumers increased their praise of experiential purchase and the interpret it also more positively. For example, compared to buy a shirt, visit a museum, has more favorable high-level significance, such as learning, cultural influence. Above characteristics and it's deep sense of awareness in museums gradually stand out in the individual over time. (Van Boven, 2005) [6]. Van Boven and Gilovich (2003) presented four choices to the subjects, each group contains the material purchase and experiential purchase as follows: a new watch or see a Broadway show, a pair of boots or dinner plus a drama, a favorite CD or go to the pool hall, a new jacket or with a friend's to enjoy coffee time. Subjects were randomly divided into three groups, these groups were set in different time: a year ago (distant past), one year later (distant future) and the second (in the near future), then subjects were asked to make a choice and assessed which purchase way can make himself happier [2]. As a result, the group of one year ago, 64\% choose experiential purchase, 72\% believe that experiential purchase can make himself happier; the group of a year later, $57 \%$ choose experiential purchase, $68 \%$ believe it can make himself happier; second day group, 50\% chose experiential purchase, 58\% believe the purchase to make himself happier. In a short, the number of subjects that choose to experiential purchase from first two group (a year ago, and after one year)were more than the group of closer distance (the next day), and they also think that experiential purchase make himself happier.

In a word, as time distance increases, experiential purchase has higher level of interpretation than material purchase and it becoming more beautiful, leaving consumers feel happy and joyful.

\subsection{Experience Has a Closer Contact with Self}

A person's life is the sum of their life experiences, such as go to school, get married, have kids, etc. Rich life experience creates a colorful life (Van Boven \& Gilovich, 2003) [2]. Besides, compared with the article, the experience is an important part of oneself (Carter \& Gilovich, 2012) [3]. Van Boven and Gilovich (2003) inquiried 76 adults about the question that "in life, experience purchase and material purchase which can better explain 'who you are'," 89\% think that experiential purchase have a more important role on self-defining [2]. Carter and Gilovich (2012) asked subjects to recall the experiential purchase and material purchases each 4 times for the past 5 years and required them to paint purchase circle around the circle stood of "self" [3]. As a result, the subjects draw the circles represented experiential purchase at the closer position of the "self”. In the same study, re- 
searchers also found that subjects were more likely to tell the story of his life through experiential purchase and more reluctant to "lose" their memories about the experiential purchase. Thus, experience is closer to individual's self-concept and self-definition (Dunn et al., 2011) [18].

But it is not concerned with articles. Article is important and pleasing, but usually just object. It is a objective reality, can separate from the owner and does not rely on individual memories. In contrast, once bought an experiential purchase, it will become part of individual memory, and generates links with individual self-concept (Klein, 2001) [20]. Meanwhile, from the perspective of motivation, experience is prone to satisfy people's intrinsic goals, and the intrinsic goals related with individual self-development (Kasser \& Ryan, 1996) [21]. Thus, compared to material purchase, experience of individual play a more active role on self-development.

Although individuals can show their identity and status to others through possessions (Belk, 1988; Richins, 1994) [22] [23], but they can not let others really know themselves. Therefore, possessions are not conducive to self-build. Carter and Gilovich (2012) asked subjects to imagine the following scenario: "A stranger A knows all your material purchase, and another stranger B knows all your experiential purchase, in addition, they know nothing about you, then which stranger more know the real you?” The results show that the subjects considered strangers B understand themselves better. Reversed the roles of subjects and strangers, the test's result is the same. In other words, people knowing their experience purchase is more know the stranger than knowing their material purchase. It is same in the context of actual intercourse, when subjects imagined a scene of an first important meet with a stranger, and only one thing can be known is that he had bought a certain time, they prefer to know about his experiential purchase rather than material purchase (Carter \& Gilovich, 2012) [3].

So why dose experiential purchase has a closer relationship with the self, and let people feel happier? First, from the perspective of memory, because the experience and itself are closer (Carter \& Gilovich, 2012) [3], the memory, gained through the experience, are leaving the individual to maintain a positive self-perception as self-serving bias (Dunning, 2005) [24]. What's more, activities and (episodic memory) experiences deepen their semantic memory (Carter \& Gilovich, 2014) [5]. With the passage of time, individuals speak highly of the experience and use memory-protecting strategy to buffer esteem threats (Dunning, 2005) [24]. Secondly, from the perspective of cognitive evaluation, intangible and subjective experience makes people easy to find the positive dimension to evaluated, although suffered from disappointment in actual experience, individuals would rather make use of their fuzziness experience to make favorable evaluation.

\subsection{Experiential Purchase Are Unlikely to Cause Social Comparison}

People managed to complete things assessment through comparing each other (Gilbert, Giesler, \& Morris, 1995) [25]. An important reason for experiential purchase more pleasurable than material purchase is that it is hard to cause social comparison, and also more resistant to unfavorable social comparisons, which can reduce the adverse effects of social comparison, thus, people can get high level of happiness (Carter \& Gilovich, 2010, 2014) [5] [9].

Firstly, the feature of item determines it is easy to compare (Carter \& Gilovich, 2010) [9]. Comparison process reduces the degree of consumer happiness. For example, after purchasing a piece of clothing, people often compared it with other clothing on styles, fabrics and so on. In real life, purchased items are not perfect and always not able to coincide with expectations. And for material purchase, there were too many things to compare, such as buying a new phone or a new car, this kind of original purchase should have brought happiness, while in seeing others have a better phone, more expensive car, the comparison minds inevitably arise, which undoubtedly lead to an unpleasant nature. In Carter and Gilovich's (2010) study, subjects were asked to imagine that one of their companions bought the same product better than yours at the same price [9]. A group of subjects buy laptops, while the other group subjects are tour packages. The results showed that the group buying laptops subjects reported satisfaction levels are significantly lower than the group with tour packages.

In contrast, the experiential purchase is less likely to cause social comparison, because experience is a personal feeling. Compared to items, experience is more unique, its comparability is relatively small (Carter \& Gilovich, 2010; Van Boven, 2005) [6] [9]. For example, to go somewhere for tourism, people will choose a different travel time, route and traveling companion, encounter different things in the journey, and have different experiences and feelings. These experiences are invisible, unique, unable to unify criteria to compare and measure, and therefore unlikely to cause relative, thereby generating less regret, loss and other emotions. Through a study, Howell and Hill (2009) found that social comparison has a negative correlation with subjective well-being, but 
the experiential purchase can reduce social comparison, thereby increasing the level of subjective well-being of consumers [10].

Secondly, the happiness brought by material purchase vulnerable generate social comparison. Carter and Gilovich (2010) found that people were compared after purchase, if found the price of similar purchase reduced or a better choice in the same article or someone else' better, the satisfaction after purchase will be weakened in great magnitude [9]. This is because people tend to make some sort of regret after material purchase, and for experiential purchase, people often feel regret because of missed it. Therefore, that experiential purchase we have made is not easy to make people regret, accordingly, satisfaction and pleasure brought by experiential purchase are not susceptible (Rosenzweig \& Gilovich, 2012) [11]. Another study (Van Boven, 2005) also confirmed the above results, the researchers let the subjects to imagine a disappointing experiential purchase or material purchase, subjects who imagine the experiential purchase feel less regret, and are more willing to make similar buying behavior in the future [6].

In short, article has a "here and now" feature, is an object, but experience is exists in consumers' memories and subjective. Therefore, article is apt to cause more evaluative comparisons. Some researchers have pointed out, to get an item is not essentially independent evaluation, its evaluation is relative, and the process of consumption of an article can be evaluated, and its evaluation is absolutely, people often can judge whether pleasant and do not need compare with others (Hsee, Yang, Li, \& Shen, 2009) [26].

\subsection{Experiential Purchase Can Meet Basic Psychological Needs Better, Especially the Relationship Needs}

According to self-determination theory (SDT), humans have three kinds of inherent basic psychological needs: autonomy need, competency needs and relational needs (Deci \& Ryan, 2000) [27]. These needs are born and indispensable in individual life. If met, these needs will bring positive consequences to individuals. But once missed, it would have a negative impact, such as damage to mental health, happiness and so on. Thus, meeting the psychological needs is the foundation of individual, happiness. Howell et al. (2012) confirmed that experiential purchase is in favor of psychological need satisfaction, so as to enhance the individual's subjective well-being. The results showed that low-materialistic values caused a high tendency for experiential purchase and a higher degree of psychological needs satisfaction, and higher levels of subjective well-being; and high materialistic values caused a low propensity for experiential purchase and low psychological needs satisfaction, resulting in lower levels of subjective well-being (Howell et al., 2012) [14].

Some researchers believe that why more people feel experience happier than the goods, because the experience and the process itself has undergone sociability, can increase the degree of interpersonal intimacy, is conducive to individual development of success social relationships (Carter \& Gilovich, 2014; Van Boven, 2005; Van Boven \& Gilovich, 2003), better promote one of three kinds of psychological basic needs-relationship need [2] [5] [6]. Thus contributing to enhance the happiness of individuals (Caprariello \& Reis, 2013; Diener \& Seligman, 2002; Thomas \& Miller, 2013) [8] [12] [28]. Such as travel, dining, outdoor activities, these are usually together with others, a participatory process of common experience, but also a communication and interaction process with others (Dunn et al., 2011); And purchase items such as clothes, tableware and computer is usually a person's behavior which is relatively isolated [18]. Howell and Hill (2009) confirms the experience of buying by increasing the degree of intimacy between people to meet the individual psychological needs, so as to enhance the vitality, and ultimately improve the well-being of individuals purchase, that indicating experiential purchase can make people happier by satisfying relationship required [10].

\subsection{Experience Is Easy to Share}

Compared to material purchase, experiential experience easier to share with others, get attention from others, thereby promoting individual pleasure (Bastos, 2012; Van Boven et al., 2010) [15] [16]. Therefore, the share purchase has an direct impact on the relationship between purchase and happiness. Bastos (2012) found that post-purchase sharing make people happier, and people are more willing to talk about the experience with others, because people associated experiential purchase with respect and think that sharing experience can get more respect from others, resulting in higher pleasure [15]. Bastos' (2012) study has an important point that is sharing the experience of purchase can get more respect [15]. Coincidentally, the researchers who had explored the differences in buyers' attitudes between experiential purchase and material purchase found that, compared to the 
experiential buyers, people have more negative evaluation on material buyers. People think that they are more selfish, self-centered; material purchase is considered driven by external motivation, such as to obtain the status, prestige, etc., and experiential purchase driven by internal motivation is from the heart, out of self-will. This led directly to a negative stereotype of people with material buyers, even can not eliminated in the face of the exchange (Van Boven et al., 2010) [16]. This shows that material purchase was stigmatized; talking about possessions with others is likely to be considered bragging. So, in public, avoiding substance-related topics and more talking, sharing experiences can make people easier and enjoyable.

The above analysis shows that the phenomenon of experiential purchase producing more happiness than material purchase can be achieved through a variety of mechanisms; these mechanisms may also play a role at different levels, hand in hand. With the advancement of research in the future, perhaps even lead to more discovery of psychological mechanisms to explain why experiential purchase bring more happiness to consumers.

\section{Future Prospect}

In summary, the present studies of experiential purchase and material purchase have made some achievements, including the definition, conception and measurement of experiential and material purchases, and the relationship between them and happiness and theoretical interpretation. However, some shortcomings still exist; researchers need to further deepen and improve. In the future, researchers may consider the following aspects at least:

\subsection{Purchase Types on the Degree of Happiness}

\subsubsection{Long-Term Effects of Types of Purchasing on Happiness}

Previous studies often let the subjects recall or imagine ever purchase, and then report the degree of happiness on such purchase, so much for measured levels of pleasure that time. They less concerned about the long-term impact on consumers' happiness, or long-term changes related to the purchase's happiness (Van Boven, 2005) [6]. Studies have shown that possessions can bring joy to consumers, but this positive sentiment is short (Richins, 2013) [29]; secondly, Nicolao et al. (2009) believes that with the passage of time, compared to material purchase, individual's adaptation of experiential purchase is slower, so the speed of reduction of experiential purchase's happiness to reduce is relatively slower [4]. In addition, although the article held on the physical form longer, and person feel the physical distance closer, their attractive ability reduced varying old, outdated. On the contrary, the experiential purchase makes others stay in the story tells; the collection of memories that happiness brings may be more persistent (Carter \& Gilovich, 2014) [5]. Therefore, future research could focus on the dimension of time, using a longitudinal study to explore the impact of time on the purchase which brings a sense of joy, in order to more accurately grasp the mechanism of purchase type's impact on happiness on the time dimension.

\subsubsection{The Boundary Condition of Purchase Type and Happiness}

Previous studies have shown that the experiential purchase is not always make people happier than material purchase; there are some boundary conditions, such as the purchase results titer (Nicolao et al., 2009), materialistic values (Millar \& Thomas, 2009) [13]. The purchase price (Carter \& Gilovich, 2010; Nicolao et al., 2009; Van Boven \& Gilovich, 2003) as well as socio-economic status (Thomas \& Millar, 2013; Zhang, Howell and Caprariello, 2013) [2] [4] [9] [12] [30].

From the self-determination theory, only making experiential purchase out of autonomous motivation can meet more basic psychological needs, so as to enhance well-being; but for the controlled motivation or a motivation, experiential purchase meets the basic psychological needs on a relatively lower degree, and the pleasure is lower. That is, to some extent, experiential purchase is able to enhance happiness depending on the extent of consumers' motivation. This may be another possible boundary condition to which future research should pay attention. Zhang et al. (2013) also developed Motivations for Experiential Buying Scale (MEBS), containing a self-motivation, controlled motivation and no motivation in three dimensions [30]. Scale is a total of 20 questions and 7:00 scoring. The scale will quantify experiential purchase motivation with good reliability and validity. It provides an effective tool for future research.

In addition, you can further explore whether there are other boundary conditions; for example when each with different levels of interpretation summarizes abstract and concrete way to remember or describe the image when buying two types purchases, does “experience recommendation” phenomena still exist? Another example is 
when an individual is in the different levels of psychological needs, the happiness brought by two purchases to the individual will make a difference? Therefore, future research needs to further investigate the effects of experiential purchase, material purchase and the relationship with happiness from a variety of angles.

\subsubsection{Role of the Different Orientation of Happiness of Purchase Types}

Current research on happiness thinks there are two different happiness: pleasure-oriented happiness (hedonia) and meaning happiness (eudaimonia). The former concerns the moment of individual happiness; the latter concerns individual future self-realization (Baumeister, Vohs, Aaker, \& Garbinsky, 2013) [31], self-growth and the SWB over time (Bauer, McAdams, \& Pals, 2008) [32], commonly used growth, authenticity, meaning and excellence as the core concepts (Huta \& Waterman, 2013) [33]. When previously studied the influence of purchase patterns on buying happiness, it only concerned with the level of consumer sentiment, that joy, using pleasure-oriented happiness. People think in terms of material purchase, experiential purchase brings more pleasure to individual. In real life, the consumer in addition to emotional happiness, but also bring other experience. For example, studies have found that people tend to incorporate the experience of self-purchase, feeling of experiential purchase and self-coupling closer (Carter \& Gilovich, 2012; Howell \& Hill, 2009), which relates to the significance level, rather than just pleasure [3] [10]. Thus, in the future we can try adding the meaning of happiness as the dependent variable, to explore the composition of happiness brought by experiential purchase and material purchase; that is whether happiness is composition of hedonia and eudaimonia or not, as well as the differences between different types of purchase of happiness component intensity, then we get a more comprehensive look at two ways to buy for consumers of mental function.

\subsection{Improvement of Existing Research Paradigm}

The vast majority of previous researches use recalling or imaging subjects' experiential purchase and material purchase to start experiment. This paradigm has some limitations, such as the lag in time, and influence of the quality of individual memory. Future studies should focus in a real social context, social cognitive processes of consumers' purchase, and how these processes affect their happiness, thereby enhancing ecological validity of studies, as a supplement of imagined memories paradigm. Nicolao's (2009) study had been a new attempt; they let two groups use "lab dollars" to choose the actual purchase, and then measure their happiness [4]. Thus, the use of vouchers to make a purchase to a certain extent is feasible; it makes the purchase from "past time" to "present tense", and it is more conducive to assess the emotional state of the consumer purchase, which is worth further attempts in the future.

Meanwhile, consumer neuroscience's emerging proposed to use neurophysiological technology to explain consumers' behavior, such as consumer preferences, consumer decision-making, etc. (Hubert \& Kenning, 2008) [34]. This opens a new area of research-oriented thought, and lets brain and nervous system such as eye tracking and functional magnetic resonance imaging (fMRI) can be used to explore the relationship between the different purchases and other types of motivation and its relationship with the happiness' level of consumer in the future.

\subsection{Carry out the Study of the Relationship between Purchase Types and Happiness in China}

We are put ongoing efforts to build a harmonious society and happy society; meeting people's basic living and raising public happiness are the keys.

With the upgrading of China's economy, the money that people can freely dispose is growing and the consumption level is also rising. In recent years, China has also appeared a phenomenon of "not rich but extravagance"; some people exhibit on unrestrained pursuit of luxury and other substances. This irrational consumption caused extravagance, waste and bad social habits. Therefore, a reasonable consumer guide for people to address the problem and enhance people happiness is an urgent need with profound social significance.

China can learn from the study of purchase types and happiness in the West; based on observation and analysis of consumer behavior on people, we can make a study of people's preference and motives of different purchase types, the relationship between the type of purchase and the people happiness and research on localization's and other aspects of its internal mechanism. At the same time, more researches needs to be translated into practice, consumer education. The researches should be proposed universal timely and consumers' consumption patterns and their relationship with their own understanding of happiness should be deepened. In addition, media 
should enhance relative propaganda and education to consumers. Meanwhile we must encourage the consumer to set up the rational expenditure conception rather than blind material pursuit. We should emphasize the consumption education of children and adolescents and try to build a healthy and positive consumption ethics. Allowing people to foster a better habit to enhance the joy and happiness of consumption: buy some more experience purchase, a little less material purchase.

\section{References}

[1] Diener, E., Horwitz, J. and Emmons, R.A. (1985) Happiness of the Very Wealthy. Social Indicators Research, 16, 263274. http://dx.doi.org/10.1007/BF00415126

[2] Van Boven, L. and Gilovich, T. (2003) To Do or to Have? That Is the Question. Journal of Personality and Social Psychology, 85, 1193-1202. http://dx.doi.org/10.1037/0022-3514.85.6.1193

[3] Carter, T.J. and Gilovich, T. (2012) I Am What I Do, Not What I Have: The Differential Centrality of Experiential and Material Purchases to the Self. Journal of Personality and Social Psychology, 102, 1304-1317. http://dx.doi.org/10.1037/a0027407

[4] Nicolao, L., Irwin, J.R. and Goodman, J.K. (2009) Happiness for Scale: Do Experiential Purchases Make Consumers Happier than Material Purchases? Journal of Consumer Research, 36, 188-198. http://dx.doi.org/10.1086/597049

[5] Carter, T.J. and Gilovich, T. (2014) Getting the Most for the Money: The Hedonic Return on Experiential and Material Purchases. In: Tatzel, M., Ed., Consumption and Well-Being Inthe Material World, Springer, Dordrecht, 49-62. http://dx.doi.org/10.1007/978-94-007-7368-4 3

[6] Van Boven, L. (2005) Experientialism, Materialism, and the Pursuit of Happiness. Review of General Psychology, 9, 132-142. http://dx.doi.org/10.1037/1089-2680.9.2.132

[7] Richins, M.L. and Dawson, S. (1992) A Consumer Values Orientation for Materialism and Its Measurement: Scale Development and Validation. Journal of Consumer Research, 19, 303-316. http://dx.doi.org/10.1086/209304

[8] Caprariello, P.A. and Reis, H.T. (2013) To Do, to Have, or to Share: Valuing of Experiences over Material Possessions Depends on the Involvement of Others. Journal of Personality and Social Psychology, 104, 199-215. http://dx.doi.org/10.1037/a0030953

[9] Carter, T.J. and Gilovich, T. (2010) The Relative Relativity of Material and Experiential Purchases. Journal of Personality and Social Psychology, 98, 146-159. http://dx.doi.org/10.1037/a0017145

[10] Howell, R.T. and Hill, G. (2009) The Mediators of Experiential Purchases: Determining the Impact of Psychological Needs Satisfaction and Comparison. Journal of Positive Psychology, 4, 511-522. http://dx.doi.org/10.1080/17439760903270993

[11] Rosenzweig, E. and Gilovich, T. (2012) Buyer’s Remorse or Missed Opportunity? Differential Regrets for Material and Experiential Purchases. Journal of Personality and Social Psychology, 102, 215-223. http://dx.doi.org/10.1037/a0024999

[12] Thomas, R. and Millar, M. (2013) The Effects of Material and Experiential Discretionary Purchases on Consumer Happiness: Moderators and Mediators. The Journal of Psychology, 147, 345-356. http://dx.doi.org/10.1080/00223980.2012.694378

[13] Millar, M. and Thomas, R. (2009) Discretionary Activity and Happiness: The Role of Materialism. Journal of Research in Personality, 43, 699-702. http://dx.doi.org/10.1016/j.jrp.2009.03.012

[14] Howell, R.T., Pchelin, P. and Iyer, R. (2012) The Preference for Experiences over Possessions: Measurement and Construct Validation of the Experiential Buying Tendency Scale. Journal of Positive Psychology, 7, 57-71. http://dx.doi.org/10.1080/17439760.2011.626791

[15] Bastos, W. (2012) Can Purchases Make Us Happier? Perhaps, If We Tell Others about Them. University of Arizona, Tucson, Unpublished Doctoral Dissertation.

[16] Boven Van, L., Campbell, M.C. and Gilovich, T. (2010) Stigmatizing Materialism: On Stereotypes and Impressions of Materialistic and Experiential Pursuits. Personality and Social Psychology Bulletin, 36, 551-563. http://dx.doi.org/10.1177/0146167210362790

[17] Nira, L. and Yaacov, T. (1998) The Role of Feasibility and Desirability Considerations in Near and Distant Future Decisions: A Test of Temporal Construal Theory. Journal of Personality and Social Psychology, 75, 5-18. http://dx.doi.org/10.1037/0022-3514.75.1.5

[18] Dunn, E.W., Gilbert, D.T. and Wilson, T.D. (2011) If Money Doesn’t Make You Happy, Then You Probably Aren’t Spending It Right. Journal of Consumer Psychology, 21, 115-125. http://dx.doi.org/10.1016/j.jcps.2011.02.002

[19] Trope, Y. and Liberman, N. (2010) Construal-Level Theory of Psychological Distance. Psychological Review, 117, 
440-463. http://dx.doi.org/10.1037/a0018963

[20] Klein, S.B. (2001) A Self to Remember: A Cognitive Neuropsychological Perspective on How Self Creates Memory and Memory Creates Self. In: Sedikides, C. and Brewer, M.B., Eds., Individual Self, Relational Self, Collective Self, Psychology Press, New York, 25-46.

[21] Kasser, T. and Ryan, R.M. (1996) Further Examining the American Dream: Differential Correlates of Intrinsic and Extrinsic Goals. Personality and Social Psychology Bulletin, 22, 280-287. http://dx.doi.org/10.1177/0146167296223006

[22] Belk, R.W. (1988) Possessions and the Extended Self. Journal of Consumer Research, 15, 139-168. http://dx.doi.org/10.1086/209154

[23] Richins, M.L. (1994) Special Possessions and the Expression of Material Values. Journal of Consumer Research, 21, 522-533. http://dx.doi.org/10.1086/209415

[24] Dunning, D. (2005) Self-Insight: Roadblocks and Detours on the Path to Knowing Thyself. Psychology Press, New York. http://dx.doi.org/10.4324/9780203337998

[25] Gilbert, D.T., Giesler, R.B. and Morris, K.A. (1995) When Comparisons Arise. Journal of Personality and Social Psychology, 69, 227-236. http://dx.doi.org/10.1037/0022-3514.69.2.227

[26] Hsee, C.K., Yang, Y., Li, N.H. and Shen, L.H. (2009) Wealth, Warmth, and Well-Being: Whether Happiness Is Relative or Absolute Depends on Whether It Is about Money, Acquisition, or Consumption. Journal of Marketing Research, 46, 396-409. http://dx.doi.org/10.1509/jmkr.46.3.396

[27] Deci, E.L. and Ryan, R.M. (2000) The "What” and "Why” of Goal Pursuits: Human Needs and the Self-Determination of Behavior. Psychological Inquiry, 11, 227-268. http://dx.doi.org/10.1207/S15327965PLI1104_01

[28] Diener, E. and Seligman, M.E.P. (2002) Very Happy People. Psychological Science, 13, 81-84. http://dx.doi.org/10.1111/1467-9280.00415

[29] Richins, M.L. (2013) When Wanting Is Better than Having: Materialism, Transformation Expectations, and ProductEvoked Emotions in the Purchase Process. Journal of Consumer Research, 40, 1-18. http://dx.doi.org/10.1086/669256

[30] Zhang, J.W., Howell, R.T. and Caprariello, P.A. (2013) Buying Life Experiences of the "Right” Reasons: A Validation of the Motivations for Experiential Buying Scale. Journal of Happiness Studies, 14, 817-842. http://dx.doi.org/10.1007/s10902-012-9357-z

[31] Baumeister, R.F., Vohs, K.D., Aaker, J.L. and Garbinsky, E.N. (2013) Some Key Differences between a Happy Life and A Meaningful Life. The Journal of Positive Psychology, 8, 505-516. http://dx.doi.org/10.1080/17439760.2013.830764

[32] Bauer, J.J., McAdams, D.P. and Pals, J.L. (2008) Narrative Identity and Eudaimonic Well-Being. Journal of Happiness Studies, 9, 81-104. http://dx.doi.org/10.1007/s10902-006-9021-6

[33] Huta, V. and Waterman, A.S. (2013) Eudaimonia and Its Distinction from Hedonia: Developing a Classification and Terminology for Understanding Conceptual and Operational Definitions. Journal of Happiness Studies, 15, 1425-1456. http://dx.doi.org/10.1007/s10902-013-9485-0

[34] Hubert, M. and Kenning, P. (2008) A Current Overview of Consumer Neuroscience. Journal of Consumer Behaviour, 7, 272-292. http://dx.doi.org/10.1002/cb.251 
Scientific Research Publishing (SCIRP) is one of the largest Open Access journal publishers. It is currently publishing more than 200 open access, online, peer-reviewed journals covering a wide range of academic disciplines. SCIRP serves the worldwide academic communities and contributes to the progress and application of science with its publication.

Other selected journals from SCIRP are listed as below. Submit your manuscript to us via either submit@scirp.org or Online Submission Portal.
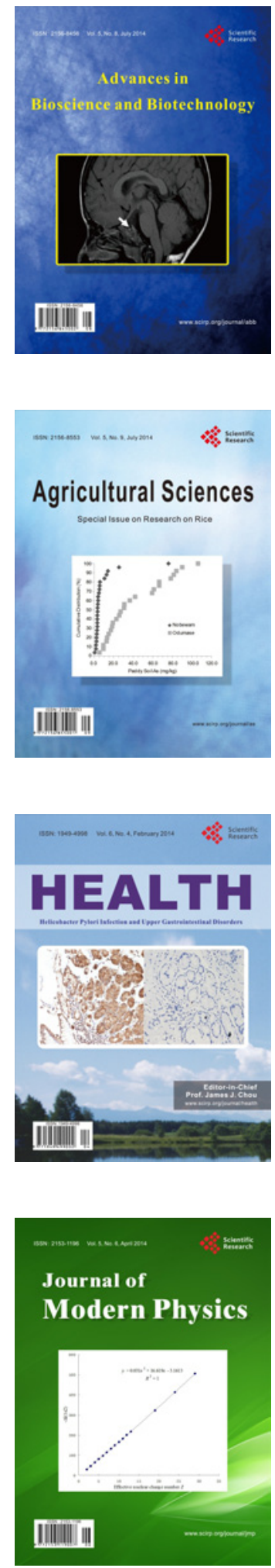
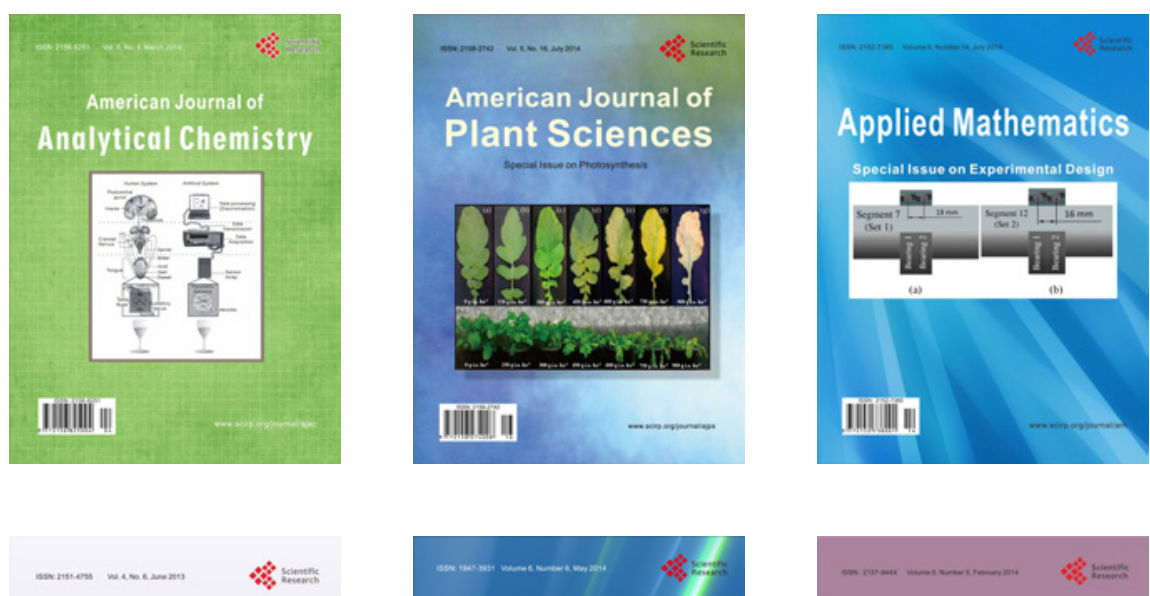

Creative Education
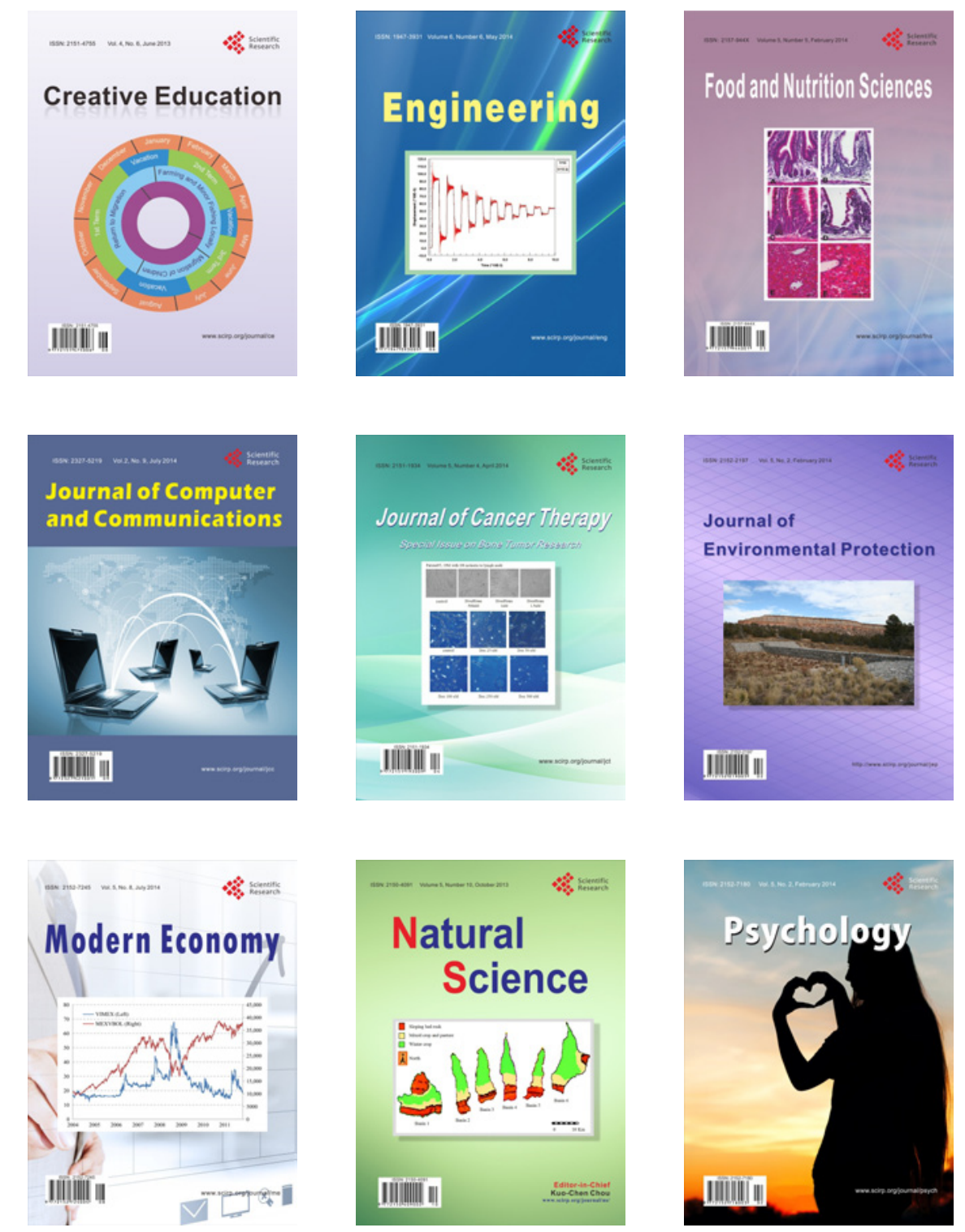